\title{
THE K-12 SENIOR HIGH SCHOOL PROGRAM: THE CASE OF LABORATORY HIGH SCHOOL, COTABATO CITY STATE POLYTECHNIC COLLEGE, SOUTH CENTRAL MINDANAO, PHILIPPINES
}

\author{
Tarhata S. Guiamalon $^{1 \star}$ and Pembain G. Hariraya ${ }^{2}$ \\ ${ }^{1}$ Assoc.Prof. Dr., Cotabato City State Polytechnic College, Philippines, \\ tarhataguiamalon@yahoo.com \\ ${ }^{2}$ Instr. MAEd, Cotabato City State Polytechnic College, Philippines, \\ pembainhariraya15@gmail.com \\ ${ }^{*}$ Corresponding Author
}

\begin{abstract}
The implementation of the K-12 Senior High School program makes Filipino students competitive globally. On this premise, a study assesses the K-12 Senior High School program of Laboratory High School (LHS) of Cotabato City State Polytechnic College (CCSPC). It also explored the resources, teachers' instructional practices, the attainment of the program's objectives and the implementation challenges. It employed descriptive-evaluative design. It administered survey questionnaires to 202 total respondents composed of 169 senior high school students who were chosen randomly and 30 teachers, including three staff, who were selected using Complete Total Enumeration. It was conducted last school year 2019-2020. Results revealed that services and resources evidently provided. The teachers LHS have evidently practiced the instructional practices in terms of teaching strategies, classroom management, and assessment of learning. Considering the findings, it was concluded that Despite the big class size and with faculty possess degrees appropriate and relevant to the high school program and other qualifications. The LHS maintains its public image of excellence in both curricular and extracurricular activities, which signifies that the Laboratory High School's instructional supervision is of a high standard.
\end{abstract}

Keywords: Assessment, K-12 Senior High School, Instructional Practices, Resources

\section{INTRODUCTION}

It looks good to improve the quality of education for global competence, but implementing it would pose a challenge for the government. Simultaneously, the Senior high school curriculum provides the student with the necessary skills for work. To some Filipino financial specialists, K-12 is an absolute necessity for the nation; unfortunately, it is not yet prepared (for it). According to Cruz (2010), the country's fate depends upon the education of the people. It is believed that with the implementation of the K-12 Senior High School program, the Philippines would make Filipino students and professionals worldwide more compatible.

The additional years in high school are believed to provide enough time to master concepts and skills, develop lifelong learners, and prepare high school graduates and middle-level skills. Increasing the number of years is not going to make it more comfortable; it'll just make it worse." In response to these negative thoughts, Luistro (2014) said, "Indeed, Department of Education is in short supply for K-12 implementation, but the government's education budget can solve the issue." There is no harm in a society that prioritizes its people's education because education is an essential element of an effective society; Luistro (2014) added (Seamolnnotech, 2010). 
One of the four (4) State Universities and Colleges (SUC's) in Region XII is Cotabato City State Polytechnic College (CCSPC), which is located at the heart of Cotabato City and caters to students from Central Mindanao. It has seven (7) academic units offering various academic programs. CCSPC, through its mandate (Batas Pambansa Blg. 484; CCSPC Code), is a government service provider in higher education in Cotabato City and individual municipalities of Central Mindanao. CCSPC is a vocational-technical institution of higher learning with various graduates, degrees, and non-degree courses.

One of its academic units is the Laboratory High School (LHS), with its initial offering was Junior High school. The CCSPC- started its operation in June 1989 with two sections in the first year. It offered a general secondary curriculum that provides a total, well-rounded development of its student's potentials. LHS offered only two (2) strands of the Senior High School (SHS), and these are Academic Track - Science, Technology, Engineering, and Mathematics (STEM) and General Academic Subjects (GAS). But during the approval of the monitoring team, the three (3) strands are approved, which is Academic Track - Science, Technology, Engineering and Mathematics (STEM), and General Academic Subjects (GAS) and Sports tracks. But only two (2) strands will be offered by the Cotabato City State Polytechnic College (CCSPC). Laboratory High School (LHS) because there are not enough classrooms for the Sports tracks and other tracks. LHS has been known as one of the best schools locally and even nationwide. Despite its glorious achievements, financial constraints caused the college management to gradually phase out the Laboratory High School as approved by the Board of Trustee Resolution No. 44,s 2003. However, its alumni, parents, and local officials appealed persistently for its re-opening. With a viable financial scheme for its smooth operation, the management and its Board of Trustees approved the re-opening of Laboratory High School effective school year 2007-2008 per Board of Trustee Resolution No. 44 series of 2007. LHS offers Junior High School and Senior High School have been born because the National Government wanted to improve the country's quality of education and compete globally and respond with the ASEAN integration program. LHS is a selfliquidating unit. Thus, this study was conceptualized to assess the implementation of the K-12 Senior High School program of Cotabato City State Polytechnic College, Laboratory High School.

\subsection{Statement of the Problem}

This study aims to assess the Implementation of K-12 Senior High School Program in Cotabato City State Polytechnic College - Laboratory High School. Specifically, the study sought to answers the following questions:

1. What is the demographic attributes of the CCSPC LHS faculty?

2. What is the extent of the provisions of services and resources?

3. What is the extent of instructional practices used by the CCSPC LHS faculty?

4. What are the challenges encountered by the CCSPC LHS administrators and teachers in the implementation of K-12 Senior High School program?

\subsection{Significance of the Study}

Acquisition of lifelong learning skills and knowledge depends on the implementation of educational program a school. The result of this study will serve as the bases for improvement and enhancement of services and it could be a good source for determining the academic success of the students.

\subsection{Literature Review}

Laboratory schools in universities and other schools were opened for teacher-training purposes. Haag (2017) opined that these schools had served many functions over the years, including teacher training, demonstration, and experimentation. She further asserted that Laboratory schools are mostly private because universities set up their charter schools. Still, there is no reason why one of those schools should not be a public institution. To Cucchiara (2010), incorporating a school on campus, the schools accept the accountability that is generally outside its field.

Evidences from research in other parts of the world pointed the great importance of resources relating quality education. Resources are necessary for any school system range from physical, human financial and others would likely motivate students to learn. Studies has shown that most of the physical facilities important to the students' successful learning or academic success today do not seem to be adequate in our public secondary schools. School is the place where students' knowledge, skills and attitude are honed and cultivated. It is a major concern of the administrators and teachers to ensure and provide quality services. Hence, a school in the most real sense is the foundation of education. It is expected that the school immediately copes and adapts to a continuously changing environment to survive (Hughes, 2014). According 
to Lunenburg and Ornstein (2013), a school is a learning organization that must be studied, including its relationship with its parts and external environment.

ICEF Monitor (2013) reported that every Filipino child could compete globally through the K-12 Basic Education Program. The additional year of mandatory kindergarten and two years of senior high school of the basic education curriculum is now a law. Accordingly, advocates of the K-12 program argue that students who went to kindergarten are better prepared for primary education than those who did not. And those who went to senior high school are ready for tertiary education, employment and are developed in middle-level skills. An additional two years of senior high school provide them sufficient time for mastery of concepts and skills.

Research results confirm that the teacher's factor improved learning. Educationally qualified teachers are considered competent in subject matter content and their strategies and techniques enabling them to be effective in classroom management. They can enhance students' performance (Darling-Hammond, 2000). The demographic attributes of the teachers may consider the qualities of teachers (Goldhaber \& Anthony 2003). Hawk et al. (1985) emphasized that licensed teachers are also regarded as effective because licensing typically requires prospective teachers to hold a college degree in pedagogy and the subject they wish to teach (Goldhaber \& Anthony 2003).

In the WENR (2018) report in Educational System Profiles-Education in the Philippines, instructors with Master's and doctoral degrees grew from 38.87 percent and 11.09 percent in 2010, respectively 40-34 and 12.62 percent in 2015. According to Carkhuff (2003), teaching is the opportunity to help others to live their lives fully, which means we help to give to our learners' lives through their physical, emotional, intellectual, and social growth. Also, Nebor (2011) opines that teachers are the backbone of the educational system. To Doyle (2014), effective teachers in difficult management situations pushed students to achieve and sustain order through the curriculum.

School plant and facilities are the material resources provided for staff and students to optimize their productivity in the teaching and learning process. The school facilities constitute the significant components of both direct and indirect elements in the environment of learning (Asiabaka, 2008). On the other hand, Ajayi and Ayodele (2001) emphasized that these resources' availability is essential to achieving effectiveness in instructional delivery and supervision in the school system. For effective teaching and learning, Okunola (1985) asserted that well-sited school plants with laboratories and sports and recreational areas might enhance and improve the school system. Also, Suleiman (2017) portends that since a child is changing rapidly, school plants and facilities, materials, and equipment in education must be changing rapidly.

According to Peretomode (2005), the concept of school plant is "those things education which enable a skillful teacher to achieve a level of instructional effectiveness that far exceeds what is possible when they are not provided. Also, Wunti (2014) defined school plant and facilities as "engines of growth in learning" to attain educational goals and objectives. In the study of Calleja (2012), it was concluded that many schools suffer due to a lack of sufficient resources, which affected the students' performance outcomes. Also, Oremeji (2017) asserted that the teacher who takes advantage of resources and learns to use them correctly could promote learning. However, Bukoye (2018) that inadequate supply and use of instructional materials in most schools' teachers did not take cognizance of the importance of instructional materials while teaching.

\section{METHODOLOGY}

The study used the descriptive research method to review relevant documents such as school forms, system-generated data of the students, and inventories. Also, survey questionnaires that elicited instructional practices were administered to 202 total respondents composed of 169 senior high school students chosen randomly and 30 teachers, including three staff selected using Complete Total Enumeration. It was conducted last school year 2019-2020. Focused group discussions and key informant interviews were conducted with the school administrators, teachers, staff, and students to identify the teachers' challenges.

The data generated from multiple sources were analyzed using the constant comparative method. Issues encountered by the school administrators, teachers, staff, and students were processed and identified by classifying. Finally, the data collected were evaluated, summarized, and presented to the LHS community.

\section{RESULTS AND DISCUSSION}

The strength and success of both Junior High and Senior High Schools depend on the provisions of services and resources; highly qualified and dedicated instructors, who have the expertise and professional experiences to supervise, facilitate and stimulate a highly inquisitive, interactive, and reflective process of 
learning.

\subsection{Demographic Attributes of the Faculty}

The CCSPC LHS faculty comprises five (6) regular faculty and twenty-four (24) Job order faculty members of CCSPC. According to the standards, rules, and guidelines, this faculty composition is based on qualification criteria for a teaching assignment in the LHS to achieve the CCSPC LHS vision, mission, and objectives. To date, the CCSPC LHS has one (1 or 3.33\%) doctoral degree holder faculty; seven (7 or $23.33 \%$ ) faculty were Master's Degree Holder in their field of specialization, and twenty-two (22 or 73.33\%) faculty were bachelor's degree holders. These results corroborate the report of the WENR (2018) In Educational System ProfilesEducation in the Philippines that the percentage of instructors with Master's and doctoral degree grew from 38.87 percent and 11.09 percent in 2010, respectively, to 40-34 and 12.62 percent in 2015.

\section{Table 1. Distribution of Faculty According to Demographic Attributes}

\begin{tabular}{|c|c|c|}
\hline Demographic Attributes & Frequency & Percentage \\
\hline \multicolumn{3}{|l|}{ Educational Attainment } \\
\hline Bachelor Degree & 22 & $73.33 \%$ \\
\hline Masters Degree & 7 & $23.33 \%$ \\
\hline Doctors Degree & 1 & $3.33 \%$ \\
\hline \multicolumn{3}{|l|}{ Eligibility } \\
\hline Licensure Examination & 16 & $57.14 \%$ \\
\hline Civil Services Examination & 2 & $7.14 \%$ \\
\hline National Competencies & 10 & $35.71 \%$ \\
\hline \multicolumn{3}{|l|}{ Number of Years of Teaching } \\
\hline 1-5 Years & 20 & $66.7 \%$ \\
\hline $6-10$ Years & 6 & $30 \%$ \\
\hline $11-15$ Years & 1 & $3.3 \%$ \\
\hline 16-Above & 3 & $10 \%$ \\
\hline \multicolumn{3}{|l|}{ Trainings Attended } \\
\hline Local & 23 & $40.35 \%$ \\
\hline Regional & 21 & $36.84 \%$ \\
\hline National & 13 & $22.81 \%$ \\
\hline \multicolumn{3}{|l|}{ Expert Services Rendered } \\
\hline Resource Speaker & 5 & $12.82 \%$ \\
\hline Accreditor & 1 & $2.56 \%$ \\
\hline Coach & 28 & $71.79 \%$ \\
\hline Officiating Officials & 5 & $12.82 \%$ \\
\hline
\end{tabular}

In addition, sixteen (16) or 57.14\% were passers of Licensure Examination on Teachers; two (2) or $7.14 \%$, and the ten (10) or $35.71 \%$ faculty who were handling the TLE program was National Certificate Holders in Cosmetology, carpentry, masonry, plumbing, electricity, bread and pastry, and commercial cooking. However, fourteen (14) of the faculty were not passers of the Licensure Examination for Teachers (LET) but the holder of NC 2. The number of years in teaching experiences indicates a high percentage of 66 . $7 \%$ for 1 to 5 years, $30 \%$ for 6 to 10 years, $10 \%$ for 16 years - above, and $3.3 \%$ for 11 to 15 years. Regarding the training attended, the faculty attended local training with $40.35 \%$, Regional $36.84 \%$, and National with $22.81 \%$. As to the expert services where the respondents rendered by the faculty, $71.79 \%$ of the faculty were coaches in the different events both academic and sports competitions. $12.82 \%$ were resource speaker in seminars, training, and workshops, and also $12.82 \%$ were officiating officials during the sports competitions. 
And 2.56\% was served as an accreditor of Accrediting Agency of Charted Colleges and Universities in the Philippines (AACCUP), Inc in State Universities and Colleges (SUCs) in Mindanao.

\subsection{Provisions of Services and Resources}

The provisions of physical facilities, equipment, library resources, office supplies, and excellent administrative services are necessary to provide a healthy learning environment for the students' pursuit of quality and excellent education. Managing these well is the key to success and growth. To provide excellent instruction to its students, the LHS provides physical resources in terms of building, classrooms, lecture rooms, offices, and equipment.

The LHS has one (1) two-story building for exclusive use by Junior High School student with twelve (12) classrooms, one (1) room for computer laboratory, one (1) room for Food Laboratory, one (1) room also for a mini-library, Prayer room and Student Supreme Government (SSG) Office. However, the number of classrooms is not sufficient since the numbers of students per section are 50 . The Dean's Office, the chairmen area, the faculty room were located on the first floor of the shared building with the Graduate College. The four (4) classrooms for Senior High Schools were located on the 2nd floor of the New Research and Extension Building. The Office has its slide projector, television, computers, overload projector, and multimedia projector. All classrooms are provided with teachers' tables and chairs, electric fan units to provide a comfortable classroom condition that is very much conducive to promoting effective teaching and learning.

In addition, the Guidance and Testing Center (GTC) of the CCSPC assists the LHS to select the best and deserving students who will; qualify to enroll in the Laboratory high the policy and guidelines on admission and retention of students are well in place. The CCSPC LHS adopts a screening mechanism and accepts only those who pass the standardized LHS High School Admission Qualifying Examination (LHSAQE) and interviews and submit complete requirements and credentials.

Further, the LHS students enjoy and have access to the physical and athletic facilities during their participation in the celebrations of athletic intramurals, social competitions, Foundation Day celebration activities, and their weekend live on the campus. CCSPC has three hectares for athletics and ball games activities such as volleyball, basketball, lawn tennis, badminton, and Sepaktakraw. It has a huge, concrete Multipurpose Grandstand, and its back portions are separate rooms for Music and Salamindanao Dance Troupe. Its gymnasium, which has a holding capacity of three thousand $(3,000)$ persons, is a center of all social, academic, and in-door sports activities. The essence of providing sports and recreational activities is to the students' need for a well-balanced educational life. This is because the Physical fitness of the body and soundness of mind is essential to students' pursuit of career advancement.

Moreover, the CCSPC administration has augmented its permanent security employees with private security force from a private security firm to ensure foremost the security and protection of the life of students, employees, and officials within the campus. Equally of paramount importance too, is the security and protection of the institutions' property and offices from harm, damage, destruction and loss, and fire.

\subsection{Faculty Instructional Practices}

The Faculty are implementers of the curriculum and are expected to give their best in teaching to achieve the ends of producing ideal graduates. To achieve excellent quality of instruction, a supervisory program was regularly prepared by the dean to provide direction and guidance in the implementation of effective instruction activities. As such, the Chairman and Senior High School coordinator conducts regular classroom visitation, observation, and assessment. Faculty members of the program are given the opportunities to attend training, workshops, and conferences to be updated with the latest trends and issues in the field of education. These continually enhance their capabilities and skills in imparting the knowledge, skills, and values to the students. Also, the quality of instruction to LHS students depends primarily on the quality of its faculty. To ensure such quality, the LHS observes strictly a well-defined system of policies, rules, and regulations on faculty attendance in their respective classes; faculty performance evaluation; faculty instruction evaluation, and awards/incentives for services and excellence. The Faculty Attendance is evidenced by a submission of the Attendance Sheet which contains the names of students present and their corresponding signature. Relative to faculty performance evaluation; this is done once for a given semester utilizing a standard Performance Evaluation Form. Each teacher is likewise observed in the class instruction by the respective Chairperson using standard Evaluation of Instruction Form. It further adopts a cross-rating system which includes: self-rating, peer rating, student rating, and supervisor's rating. Likewise, the College has established a System of Awards and Incentives to its faculty in order to encourage their creativity, innovativeness, efficiency, integrity, and productivity in the public service. 
As presented in Table 2 the faculty manifests a very high sense of responsibility and professionalism in the discharge of their major function to teach at their best as role models and change-agent; and they take into account their compliance to prescribed requirements. As glean in Table 2, the result of the study corroborates the notion of Danielson, (2007); Stronge et al., (2011). That the teacher's practices such as the learning environment, instructional delivery, personal qualities, and student assessment are the indicators of effective teaching (Danielson, 2007; Marzano, 2003; Rivkin et al., 2005; Schachter, 2012). Also to (King \& Watson, 2010; Marzano, 2003), teaching can be labeled as both an art and a science. Their teaching methodology employs both eclectic and dialectic approaches, in order to challenge high-level critical thinking and highly interactive/reactive exchange of ideas and thoughts. Classroom instruction is enriched with seminars, lectures, symposia, brainstorming, group dynamics, reporting, workshop, field trips, case studies, and laboratory. In addition, students have course requirements that challenge their ability and competence for independent study as a group/individual reports, individual term papers, and written examinations. The CCSPC LHS has established an Instructional Materials Development Committee that evaluates and recommends the instructional materials for production by the faculty for its utilization in the classroom.

Table 2. Extent of Faculty Instructional Practices

\begin{tabular}{|c|c|c|}
\hline Instructional Practices & Mean & Interpretation \\
\hline \multicolumn{3}{|l|}{ Instructional Practices } \\
\hline Teaching Strategies & 3.31 & Evident \\
\hline Instructional Materials & 3.31 & Evident \\
\hline \multicolumn{3}{|l|}{ Development } \\
\hline Assessment of students & 3.10 & Evident \\
\hline \multicolumn{3}{|l|}{ Learning Performance } \\
\hline Total & 3.24 & Evident \\
\hline
\end{tabular}

Legend:

$\begin{array}{lll}\text { 3.50-4.50 Highly Evident } & 1.50-2.49 & \text { Less Evident } \\ \text { 2.50-3.49 Evident } & 1.00-1.49 & \text { Least Evident }\end{array}$

Further, to enhance instruction, faculty encourage the utilization of PowerPoint presentation delivery of oral reports for the given topics, and provisions of hard copies to each student for independent study. The faculty likewise uses recent edition references and that its contents are related to their subjects. Preparation and submission of syllabi is a moral responsibility of the faculty. It is a mechanism that measures the scope and extent to which ends and means of each course or subject designed by an instructor are achieved. It serves as the Master Plan to control the direction in the management, implementation, and evaluation of instruction. It provides direction and guidance to students regarding the scope of subject matter, methodology, evaluation, and grading system. Alber (2015) highlighted five effective classroom practices: teacher clarity, classroom discussion, feedback, formative assessments, and metacognitive strategies. Since teachers play a critical role in promoting learning, teachers must possess competency in four categories: instructional delivery, classroom management, formative assessment, and personal competencies. According to Pack (2016), as cited by Magno (2019), during the 21st century, people worldwide discover and even practice and comprehend the things surrounding them in many innovative and diverse traditions. He further emphasized that Globalization, international mobilization, and technological innovations are some demands of the future. Therefore the student must be equipped with the knowledge, skills, attitudes, and other personal qualities.

It is an assurance by the Dean that $100 \%$ of the faculty has submitted to the Office both Table Specification (TOS) and copies of the four grading period's questions. In the assessment of students' academic performance, the faculty strictly observes the prescribed grading system. The students are fully aware and understand the student evaluation system since these are embodied in the Student Handbook. These are emphasized during Orientation Meetings at the beginning of each school year. Requirements and examination papers already checked are returned to students for their reference. True to its objectives to 
breed a higher sense of professionalism and ethical character for its students as responsible individuals and learn much from actual engagement in the class instructions, students are fully informed of the policy on checking their regular attendance. Such attendance serves as one basis in computing the grades for participation, which is a factor in measuring students' academic performance. In a highly interactive mode of instruction delivery and its smooth conduct, instructors maintain an atmosphere of discipline following democratic practices, considering that the number of students in most subjects reaches 50 students. In addition, students have requirements that challenge their ability and competence for independent study as group/individual reports, individual term papers, and written examinations.

For a smooth and systematic process, monthly meetings and consultation meetings with stakeholders were formal and diplomatic, following the parliamentary procedures. Respect for opinions was upheld, and critical analysis and comments were taken appreciatively, justifying the use of terms for appropriate description and resolving contracting ideas or views.

\subsection{Challenges Encountered}

A focus group discussion was conducted to identify the school administrators, teachers, staff, and students' challenges.

\section{a. Lack of permanent position allotted for faculty}

As a self-liquidating unit and not included in school Maintenance and Other Operating Expenses (MOOE) and budget allocation for the higher education of the Department of Budget and Management (DBM), the full operation of the LHS including the salary of faculty is taken solely from the tuition fees of the students. This is the reason why faculty do not last in LHS. They transfer and look for a job where they have security and tenure.

\section{b. Limited participation of faculty in training and seminars}

Since LHS is self-liquidating and funds are utilized for faculty salaries, not all faculty can attend training and seminars. They can only participate if the seminar is sponsored by the bookstore where the school buys. This is not enough because the seminar and training they offer are about the content of the book they will sell. Of course, faculty also needs professional training such as classroom management, teaching strategies and techniques, and modern classroom management, especially teaching innovations.

\section{c. Lack Speech laboratory, Technology Livelihood Education shops, Audio-Visual rooms}

As of to date, only the College department has its speech laboratory, shops, and audio-visual room in which this is important in providing learning experiences that will enhance the students' practical skills, increasing understanding and cultivating student interest in schooling. With the large population of students in the college department, usually, LHS will no longer use or use their laboratories. LHS only has a food laboratory and computer laboratory.

\section{d. Lack of Funds}

To fund all school activities during enrolment, LHS charges club fees. It is used throughout the year. Usually, it is not enough because there are more activities like academic competitions, sports, and so on. Because of this, students are contributing to augment the expenses intended for school activities. This is also why some parents complain because; they say they are running out of money to contribute. Sometimes it is the faculty who make the way where and how to finance the school activity.

\section{d. Class size}

The strands offered by LHS are limited; they are the general academic strand (GAS) and science, technology, engineering, technology, and mathematics (STEM). Each strand has only one section, and the number of students ranges from 45 to 50 per section. It does not meet the standard class size of a class. Due to the teacher-student ratio's size, the classroom is overcrowded, no longer conducive, and the faculty has difficulty managing the class resulting in low school performance.

\subsection{Conclusion}

Despite the big class size and with faculty possess degrees appropriate and relevant to the high school program and other qualifications, the LHS maintains its public image of excellence in both curricular and extracurricular activities. This public image has been a sign that instructional supervision of the Laboratory High School is of a high standard. 


\subsection{Recommendations}

Based on the findings of the study, the following action points should be considered by the institution.

1. Giving permanent status to Job Order faculty shall be given priority to retain qualified faculty.

2. Sending faculty to training, seminars, and workshops may be considered to help them grow more in their profession and learn more various teaching strategies to be used in teaching.

3. Provisions of Speech laboratory, Technology Livelihood Education shops, and Audio-Visual rooms may be considered in enhancing the knowledge, value, and skills.

4. Capital Outlay and Maintenance and Other Operating Expenses (MOOE) allocation for Laboratory High school may be considered since the miscellaneous fee to augment the LHS expenses.

5. To meet the standard class size and to enhance the student's learning and performance. Faculty-student ratios may be reduced.

\section{ACKNOWLEDGMENT}

The completion of this paper has been accomplished with the guidance and support of the College President of CCSPC. We would also like our gratitude to our senior high school coordinator and the faculty of CCSPC Laboratory High School for helping us in gathering the data.

\section{REFERENCE LIST}

Albert, R. (2015). 5 Highly effective teaching practices. https://www.edopia.org/blog/5-highly-effectiveteaching-parctices-rebecca-alber.

Asiabaka,I.P. (2008). The Need for Effective Facility Management in Schools in Nigeria. Department of

Education Foundations and Administration, Faculty of Education. Imo State University, Owerri, Nigeria. New York Science Journal.

Bukoye, R. (2018). Utilization of Instruction Materials as Tools for Effective Academic Performance of

Students: Implications for Counseling. Presented at the $2^{\text {nd }}$ innovative and Creative Education and Teaching International Conference (ICETIC2018), Spain, 20-22 June 2018.

Calleja, Nina (2012). K to 12 System: Grade 1 and 7 Teachers Face Challenge. Philippines Daily Inquirer.

Carkhuff, Y.K. (2033). Strategies for effective Teaching. New York: McGraw-Hill.

Cucchiara, M. (2010). New Goals, Familiar Challenges? A Brief History of University-Run

Schools.http://www.urbanedjournal.org/archive/volume7-issue-1-summer-2010/new-goals-familiarchallenges-brief-histroy-university-run-scho

Danielson, C. (2007). Enhancing professional practice: A framework for teaching. (2nd ed.). Alexandria, VA:

Association for Supervision and Curriculum Development.

Darling-Hammond, L. (2000) Teacher Quality and Student Achievement: A Review of State Policy Evidence,

Educational Policy Analysis Archives, 8(1), viewed 9 June 2004.

Doyle, R. (2014). Self-determination and Persistence in a Real Life Setting: Toward a Motivational Model of

High School Dropout. Journal of Personality and Social Psychology, 72, 1161-1176.

Goodlad, J. (1995). Foreword In Osguthorpe, et al., (Eds.). Partner Schools: Centers for Educational

Renewal. San Francisco: Jossey Bass.

Goldhaber, D. and Anthony, E. (2003) Teacher Quality and Student Achievement. ERIC Clearinghouse on

Urban Education Urban Diversity Series,

http://www.eric.ed.gov/ERICWebPortal/Home.portal?_nfpb=true\&ERICExtSea

rch_SearchValue_0=Goldhaber+\%26+Anthony\&ERICExtSearch_SearchType_0=authors\&_pageLa 
bel=RecordDetails\&objectld=0900000b8011 f92e.

Haag, P. (2017). Laboratory schools: a New Educational Phenomenon.

https://theconversation.com/laboratory-schools-a-new-educational-phenomenon-79071

Hawk, P., Coble, C.R. and Swanson, M. (1985) Certification: It Does Matter, Journal of Teacher Education, vol. 36, no. 3, pp. 13-15.

Hughes, K. (2014). The Effect of Classroom Management Strategies on Math Fluency Growth Rate. Doctoral Dissertation. retrieved September 6, 2019 from https://shareok.org/bitstream/handle/11244/14895/hughes_okstate 0664D_13201.pdf?sequence=1.

Hunkins, F.P., Wiseman, D.L, \& Williams, R.C. (1995). Supporting Collaborative Inquiry. In R. T. Osguthorpe, R. C. Harris,

ICEF Monitor (2013). Philippines creates opportunities in overhaul of K-12 education system.

https://monitor.icef.com/2013/08/philippines-creates-opportunities-in-overhaul-of-k-12-educationsystem/

King, S. H., \& Watson, A. (2010). Teaching excellence for all our students. Theory Into Practice, 49, 175-184. doi: 10.1080/00405841.2010.487751

Lunenburg, F. \& Ornstein A. (2013). “Educational Administration, Educational Management Translation”.

Marzano, R. J. (2003). What works in schools: Translating research into action. Alexandria, VA: Association for Supervision and Curriculum Development.

Nebor, H. (2011). Conceptualizing Teacher Professional Learning. Review Of Educational research, Retrieved from SAGE Journals Database 81 (13), 376-407,

Oremeji. (2017). Meeting the Challenge of Accessibility and Utilization of English Language Materials in

Rural Secondary Schools in Nigeria. International Journal of Multidisciplinary Studies I, (2): 1-13.

Orleans, A. (2007). The Condition of Secondary School Physics Education in the Philippines: Recent

Developments and Remaining Challenges for Substantive Improvements. The Australian Educational Researcher, Volume 34, Number 1, April 2007

Peretomode, V.F (2205). Introduction to Educational Administration and supervisor: Educational Trust Fund Intervention (edited) Delta State University, Educational Research and Publishers Limited. Abraka: Joja

Rivkin, S. G., Hanushek, E. A., \& Kain, J. F. (2005). Teachers, schools, and academic achievement. Econometrica, 73(2), 417-458. Retrieved from http://www.jstor.org/stable/3598793

Schachter, R. (2012). Brave new world of teacher evaluation. District Administration, 43-47.

Stronge, J. H., Ward, T. J., \& Grant, L. W. (2011). What makes good teachers good? A cross-case analysis of the connection between teacher effectiveness and student achievement. Journal of Teacher Education, 62(4), 339-355. doi:10.1177/0022487111404241

Suleiman, Y. (2007). The Relationship Between Human Material Resources and Academic Performance Among Students of Adamawa Secondary Schools: Maiduguri Journal of Arts and Social Sciences (MAJASS) volume 1,\#1.

WENR (2018). Education in the Philippines. Educational System Profiles. World Education News \& Review. https://wenr.wes.org

Wunti, Y.I (2014). Impact of the School Plant and Facilities on Students Academic Achievement in Senior Secondary Schools in Banchi State; Nigeria. Unpublished PhD Thesis, Bayero University, Kano Nigeria. 